\title{
ТОВАРОЗНАВЧИЙ АНАЛІЗ РИНКУ ДЕЗІНФЕКЦІЙНИХ ЗАСОБІВ
}

Товарознавчий аналіз ринку дезінфекційних засобів ю. А. Равлів, Я. В. Соловей

Тернопільський національний медичний університет імені І. Я. Горбачевського МОЗ України

Резюме. Під поняттям дезінфрекція розуміють знищення чи видалення мікроорганізмів на різних об'єктах й у різних субстратах навколишнього середовища з метою переривання механізму передавання інфеекційних збудників. Актуальним $є$ дослідження фрармацевтичного ринку щодо наявності дезінфрекційних засобів для забезпечення належних санітарних та протиепідемічних заходів.

Мета дослідження - провести товарознавчий аналіз вітчизняного ринку дезінфрекційних засобів.

Матеріали і методи. Встановити фрірми-виробники та країни, які постачають дезінфекційні засоби на ринок України. Дослідити фрорми їх випуску.

Результати. Серед країн-виробників дезінфрекційних засобів лідирують вітчизняні виробники, які займають 59 \% ринку. Серед країн-імпортерів лідируючу роль займають Бельгія (ТОВ «Еколаб») - 9 \% ринку та Німеччина (B. Braun Melsungen AG) - 6 \%, Італія, Нідерланди, Словаччина, Росія та Білорусь по 4 \%, Швейцарія - 3 \%, Китай та Франція - $2 \%$.

Висновки. Отримані результати дозволили встановити лідерів дезінфекційних засобів на ринку України, найбільшу частку становлять вітчизняні виробники та серед іноземних країн-постачальників лідируючу роль займає Бельгія.

Ключові слова: дезінфекція; дезінфекційний засіб; виробники; товарознавчий аналіз.

\section{ВСТУП}

На сьогодні дезінфекція має важливе значення не лише для пацієнтів, але для медичних працівників, які найбільше схильні до ризику зараження різними вірусними іноекціями у зв'язку з тим, що їх робота пов'язана з постійним контактом із біологічними матеріалами людини [1]. Дезінфекція - це комплекс заходів, спрямованих на обробку приміщень, поверхонь, інструментарію та інших об'єктів зовнішнього середовища, з метою їх очищення від різних хвороботворних мікроорганізмів. Особливу увагу приділяють дезінфекції в закладах охорони здоров'я. Саме усі приміщення в медичних організаціях підлягають обов'язковій санітарній обробці. Нездатність правильно дезінфрікувати або стерилізувати приміщення, поверхні, багаторазове медич(сЮ. А. Равлів, Я. В. Соловей, 2020
Commodity analysis of disinfectants

Y. A. Ravliv, Ya. V. Solovey

I. Horbachevsky Ternopil National Medical University

e-mail: ravliv@tdmu.edu.ua

Summary. The term disinfection means the destruction or removal of microorganisms at different sites and in different environmental substrates in order to interrupt the mechanism of transmission of infectious agents. Pharmaceutical market research into the availability of disinfectants to ensure proper sanitation and anti-epidemic measures is relevant.

The aim of the study - to carry out commodity analysis of the domestic market of disinfectants.

Materials and Methods. Establishment of manufacturers and countries that supply disinfectants to the Ukrainian market; investigating the release forms of disinfectants.

Results. Among the manufacturers of disinfectants, the leading role is played by domestic producers, who occupy $59 \%$ of the market. Disinfectants from 17 countries. Among importing countries, Belgium (Ecolab LLC) holds the leading $9 \%$ of the market and Germany (B. Braun Melsungen AG) $6 \%$, Italy, the Netherlands, Slovakia, Russia and Belarus each $4 \%$, Switzerland - $3 \%$, China and France $-2 \%$.

Conclusions. The results have made it possible to establish leaders of disinfectants in the market of Ukraine, in particular, Ukraine has the largest share of domestic producers and Belgium has a leading role among foreign suppliers.

Key words: disinfection; disinfectant; manufacturers; commodity analysis.

не обладнання може призвести до зараження медперсоналу і пацієнтів, а також до стрімкого розвитку внутрішньолікарняних інсеекцій [2].

За сучасними уявленнями ідеальні дезінфекційні засоби мають володіти як мінімум широким спектром антимікробної активності, швидкою мікобактеріальною дією, легким відмиванням з виробів, відсутністю подразнювальної дії або запаху, тривалим терміном придатності, зберігання, відсутністю проблеми утилізації відпрацьованого розчину [3].

На даний час підвищення санітарно-епідеміологічних заходів у зв'язку із розповсюдженням різних інсрекцій приводить до вивчення фрармацевтичного ринку дезінсеекційних засобів для забезпечення ліквідації накопичення, розмноження 
патогенних мікроорганізмів та своєчасному видаленню їх з поверхні, а також для розривання ланцюга передавання збудників. Отже, актуальним для медичної сестри є вивчення орармацевтичного ринку даної групи товарів [4-6].

Метою дослідження було провести товарознавчий аналіз вітчизняного ринку дезінфекційних засобів.

\section{МАТЕРІАЛИ І МЕТОДИ}

Загальноприйняті статистичні та маркетингові дослідження паперових електронних джерел інфрормації щодо дезінфрекційних засобів [7].

\section{РЕЗУЛЬТАТИ ТА ОБГОВОРЕННЯ}

Для досягнення поставленої мети було проведено товарознавчий аналіз вітчизняного ринку дезінфекційних засобів. Встановлено, що у 2019 р. в Україні зареєстровано 222 дезінорекційних засоби. Вітчизняне виробництво їх забезпечують ТОВ «Бланідас», ТОВ «ВП «Біолонг», ПАТ «Дніпроазот», ТОВ «БІОНІК», ПрАТ «Технолог», ТОВ «Інтердез», ТОВ «Владасепт», ТОВ «ДЕЗАНТ», ТОВ «ВІОЛА МЕДТЕХНІКА», ТОВ «Феліцата Україна», ТОВ Науково-виробниче підприємство «Біоцид», TOB Науково-технологічний центр «Вербена», ТОВ «Еколаб ТзОВ» на виробничих потужностях ТОВ «Інтерфілл», ТОВ «Українські Хімічні Технології ЛТД», ТОВ «ГРІНПАКС», ТОВ «МДМ», ТОВ «Делана», ТзОВ «ОРДЕМА», ТзОВ «АгроМаксі», ТОВ «ЛАБОРАТОРІЯ АНТИСЕПТИКИ», ТОВ «ІНДУСТРІАЛЬНЕ МИЮЧЕ ОБЛАДНАННЯ», ТОВ НВП «КРИСТАЛ ГАЛИЧИНА», ТОВ «ГРЕНЛАНДІЯ», ТОВ «Технохімреагент», ТОВ «Івахім», ТОВ «Торговий дім «Санітарний щит України», ТОВ «XIЛЕР», ТОВ «Спецтехнологія», ТОВ «Фабрика агрохімікатів», ТОВ «ТОРГІВЕЛЬНО-ПРОМИСЛОВИЙ БУДИНОК «УСАДЬБА-АГРОХІМ», ТОВ «Лаверна», ПП «Фармацевтична фрабрика «НФО «Ельфра», ТОВ «ХімСервісГруп», ТзОВ «Пологівський хімічний завод «Коагулянт».

Таким чином, серед країн-виробників дезінфрекційних засобів лідирують вітчизняні виробники, які займають 59 \% ринку. Дезінфекційні засоби на український ринок постачають фрірми-виробники із 17 країн світу. Аналіз державного реєстру дозволив встановити частку кожної із країн-виробниківутоварномуасортименті. Серед країн-імпортерів лідируючу роль займають Бельгія (ТОВ «Еколаб») - 9 \% ринку та Німеччина (B. Braun Melsungen AG) -6 \%, Італія, Нідерланди, Словаччина, Росія та Білорусь по 4 \%, Швейцарія - 3 \%, Китай та Франція - 2 \%. Швеція, Польща, Естонія, Ірландія, Румунія,
Чехія та Малайзія займають лише 1 \% вітчизняного ринку. Результати показано на рисунку 1.

Також були проведені дослідження щодо їх фрорми. Найбільшу кількість на ринку займають розчини та гелі - $95 \%$, таблетки і серветки - по 2 \%, порошки - 1\%. Результати проведених досліджень подано на рисунку 2.

При вивченні Державного реєстру було встановлено, що він містить 432 позиції товарів для дезіндекції та дезінсекції у 2011 р., а в 2019 р. зареєстровано 222 товари, що говорить про зменшення насичення ринку засобами для дезінфрекції $[8,9]$.

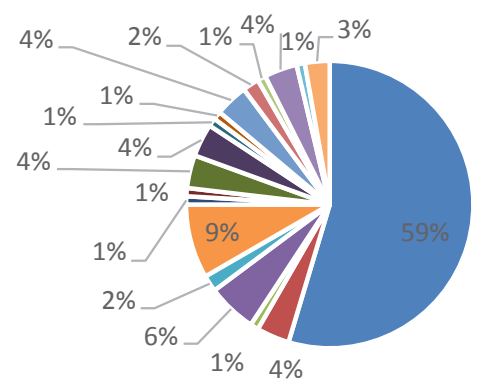

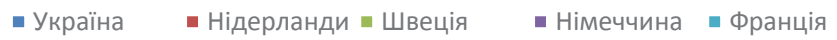

$$
\begin{aligned}
& \text { - Бельгія - Польща Естонія - Білорусь - Італія } \\
& \text { - Ірландія - Румунія " Словаччина - Китай } \\
& \text { - Росія - Малайзія - Швейцарія }
\end{aligned}
$$

Рис.1. Країни-виробники дезінфекційних засобів.

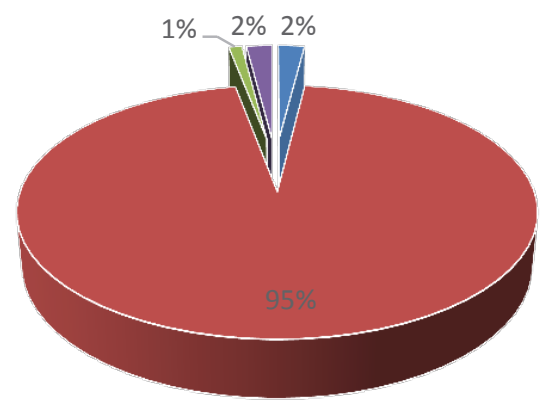

- Таблетки - Розчини - Порошки - Серветки

Рис.2. Форма випуску дезінфекційних засобів.

\section{ВИСновкИ}

У результаті проведеного товарознавчого аналізу було встановлено, що серед виробників дезінфекційних засобів лідирує Україна (59 \%). Імпорт засобів здійснюють із 17 країн світу. Найбільшу частку ринку займають Бельгія (9%) та Німеччина (6 \%). Серед форми дезінфекційних засобів найбільше на ринку наявні розчини і гелі, що становить $95 \%$. 


\section{СПИСОК ЛІТЕРАТУРИ}

1. Сіда Л. Л. Екологічна безпека застосування дезінфкуючих засобів / Л. Л. Сіда . - І Всеукраїнський з"їзд екологів : Міжнар. наук.-техн. конф.: тези допов. - С. 213.

2. Морозова Н. С. Дезінфректологія. Стерилізація, дезінфекція, дератизація : підручник для студентів вищих навчальних закладів медичного профрілю / Н. С. Морозова, В. Ф. Марієвський. - К. : Наукова думка, 2019. $-240 \mathrm{c}$.

3. Колосовская Е. Н. Современное состояние выбора дезинфицирующих средств в лечебно-профилактических учреждениях / Е. Н. Колосовская, И. Г. Терехова // Terra Medica. - 2010. - С. 13-18.

4. Гущук І. Довідник головної медичної сестри / І. Гущук , Д. Пархоменко // Практичні аспекти організації санітарно-протиепідемічного режиму. - К. : ТОВ «МЦФЕРУкраїна», 2015. - С. 14-19.

5. Актуальні проблеми підвищення ефективності дезінфекційних заходів в лікувально-профрілактичних закладах / Н. С. Морозова, С. В. Рідний, О.О.Попов [та ін.] // Актуальні проблеми транспортної медицини. - 2015. № 1 (39). - С. 72-76.

\section{REFERENCES}

1. Sida LL. Environmental safety of disinfectants. 1st All-Ukrainian Congress of Ecologists: Int. scientific-technical conf .: these additions. Ukrainian.

2. Morozova N.S, Marievsky V.F Disinfection. Sterilization, disinfection, deratization: a textbook for students of higher educational establishments of medical profile. [Стерилізація, дезінфекція, дератизація : підручник для студентів вищих навчальних закладів медичного профрілю] Kyiv: Naukova dumka; 2019. Ukrainian.

3. Kolosovskaya EN, Terekhova IG [The current state of the choice of disinfectants in medical institutions]. Terra Medica. 2010;1: 13-8. Russian.

4. Hushchuk I, Parkhomenko D. Handbook of the Chief Nurse Practical Aspects of the Organization of the Sanitaryand-Epidemic Regime. [Довідник головної медичної сек стри. Практичні аспекти організації санітарно-протиепіғ демічного режиму] Kyiv: MCFER-Ukraine LLC. Ukrainian.

5. Morozova NS, Rodnyi SV, Popov OO, Hrytsai IM, Dekhtiar OV, Korobkova II. [Actual problems of increasing the effectiveness of disinfection measures in medical establishments]. Aktual prob transport med. 2015;1(39): 72 6. Ukrainian.
6. Актуальні питання дезінфектології: токсикологія, гігієна, епідеміологія : матеріали науково-практичної конореренції. - К., 2003. - С.340.

7. Реєстр на деззасоби станом на 2019p https://moz. gov.ua/uploads/ckeditor/\%D0\%92\%D1\%96\%D0\%B4\%D0 \%BA\%D1\%80\%D0\%B8\%D1\%82\%D1\%96\%20\%D0\%B4 \%D0\%B0\%D0\%BD\%D1\%96/\%D0\%A0\%D0\%B5\%D1\%9 4\%D1\%81\%D1\%82\%D1\%80\%20\%D0\%BD\%D0\%B0\%20 \%D0\%B4\%D0\%B5\%D0\%B7\%D0\%B7\%D0\%B0\%D1\%81 \%D0\%BE\%D0\%B1\%D0\%B8\%202019.pdf

8. Івко Т. І. Товарознавчий аналіз дезінорікуючих засобів на фрармацевтичному ринку України / Т. І. Івко, Т. А. Германюк, І. І. Баранова // Товарознавчий аналіз товарів аптечного асортименту : матеріали IV наук.-практ. internet-конф. 3 міжнар. участю, м. Харків, 6 квіт. 2018 р. - Х. : вид-во НФаУ, 2018. - С. 25.

9. Аналіз ринку дезінфокуючих засобів в Україні / О. І. Касяненко, А. В. Березовський, С. М. Касяненко, Р. В. Долбоносова // Науково-технічний бюлетень Державного науково-дослідного контрольного інституту ветеринарних препаратів та кормових добавок і Інституту біології тварин. -2019. - № 20(2). - С. 439-445.

6. Topical issues of disinfection: toxicology, hygiene, epidemiology. Materials of scientific and practical conference. Kyiv; 2003. Ukrainian.

7. The registry for disinfectants as of $2019 \mathrm{https}: / / \mathrm{moz}$. gov.ua/uploads/ckeditor/\%D0\%92\%D1\%96\%D0\%B4\%D0 \%BA\%D1\%80\%D0\%B8\%D1\%82\%D1\%96\%20\%D0\%B4 \%D0\%B0\%D0\%BD\%D1\%96/\%D0\%A0\%D0\%B5\%D1\%9 4\%D1\%81\%D1\%82\%D1\%80\%20\%D0\%BD\%D0\%B0\%20 \%D0\%B4\%D0\%B5\%D0\%B7\%D0\%B7\%D0\%B0\%D1\%81 \%D0\%BE\%D0\%B1\%D0\%B8\%202019.pdf

8. Ivko TI, Hermaniuk TA, Baranova II. Commodity analysis of disinfectants in the pharmaceutical market of Ukraine. Commodity analysis of products of pharmacy assortment: materials IV scientific-practical. internet conf. from the international. participation, Kharkiv; 2018. Ukrainian.

9. Kasianenko, OI, Berezovskyi AV, Kasianenko SM, Dolbonosova RV. Analysis of the market of disinfectants in Ukraine. Scientific and Technical Bulletin of State Scientific Research Control Institute of Veterinary Medical Products and Fodder Additives and Institute of Animal Biology. 2019;20(2): 439-45. Ukrainian. 